\title{
Human-environment relationships in modern and postmodern geography
}

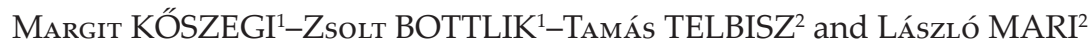

\begin{abstract}
In this article we analyse the human-environment relationships in geographical research from the end of the $19^{\text {th }}$ to the beginning of the $21^{\text {st }}$ century. We highlight paradigms, which affected our way of thinking about man-environment relations. Discussing scientific approaches and paradigms in geography the leading scientists who had influential thoughts and helped the shaping of a paradigm will also be mentioned. The research on human-environment relations has appeared in geography from time to time, but the connecting paradigms had also different stories through time and space. Undoubtedly, the nowadays reviving determinism had the greatest influence, but possibilism has also had a significant impact on our discipline. Research on human-environment relationships reappeared in a new form through the discourse on global climate change. Postmodern, poststructuralist, and postcolonial approaches changed radically the basis of human-environment research. In this paper, we argue that geography needs to renew not only its philosophical basis and theoretical context, but the connections between the two subdisciplines of geography (i.e. between physical and human geography) must be refreshed too.
\end{abstract}

Keywords: human-environment relations, determinism, possibilism, ecology, climate change

\section{Introduction}

Climate change discourse draws the attention again to the relationship between humans and nature. The widely available and diversified information about this issue has had a significant impact on public opinion and political decision making, therefore, the knowledge of the theoretical background of these scientific approaches is very important. Research on human-environment relationships has been present in geography from the very beginning. Definitely, it had great importance in the process of becoming an academic discipline in the $19^{\text {th }}$ century, and it contributed to the duality of geography and brought about the development of anthropogeography (i.e. human geography).

In this paper we analyse the changing contexts of geography from the end of the $19^{\text {th }}$ to the beginning of the $21^{\text {st }}$ century. We highlight paradigms, which ruled our way of thinking about human-environment relations. Undoubtedly, the nowadays reviving determinism has had the greatest influence, but possibilism also had a significant impact on our discipline. Beside theoretical considerations, the actual reason for the present paper is a joint physical and human geographical effort. Our research group works on the exploration of some aspects of the manenvironment relationships within selected spatial units (Montenegro in Telbisz, T. et al. 2014a; Gömör-Torna Karst in Telbisz, T. et al. 2014b and the Apuseni Mountains ["Erdélyiszigethegység" in Hungarian] in Telbisz, T. et al. 2014c). Karst terrains have several special physical characteristics, namely the hy-

\footnotetext{
${ }^{1}$ Department of Regional Science, Eötvös Loránd University, H-1117 Budapest, Pázmány Péter sétány 1/C. E-mails: koszegimargo@gmail.com, agria@gmx.net

${ }^{2}$ Department of Physical Geography, Eötvös Loránd University, H-1117 Budapest, Pázmány Péter sétány 1/C. E-mails: telbisztom@caesar. elte.hu, mari.laci@gmail.com
} 
drology, the soils. The relief is different from those of other terrains. Thus, we studied whether and how these physical settings (e.g. the lack of water, natural monuments, poor soils, etc.) influence social features like settlement patterns, population changes, transport network etc. Our approach is modern as we used GIS methodology but the studied problems have a long-standing history in geographical thoughts.

\section{The foundations of scientific thinking: the society-nature dichotomy}

Science has a well-defined though not always conscious philosophical view in the background of investigations concerning the relationships between humans and nature: the separation of society from nature. This dichotomy permits the simplification of complex systems and the research of subsystems (Harden, C.P. 2012). According to JudKINs, G. et al. (2008, p. 19) "the separation of humankind from nature, and the search for determinism within this relationship, are mutually constitutive and appear to varying degrees during all moments of human-environment research".

Investigation of human-environment relations is one of the most basic questions of humankind. We can use the classical phrase that already the ancient Greeks had tried to explain, but we can go back even further, to the old myths of creation too. However, it was only in the second half of the $19^{\text {th }}$ century when this research issue was considered as part of the academic science of geography.

Zoltán HAJDú (2007) considers this theme in a wider context. He agrees that this is one of the fundamental questions of geography, and further on, he introduces the evolution of scientific thinking in connection with these relationships. Basically, there are two contrasting viewpoints in science that have accompanied human history. The first is that environment controls social processes (determinism), and the second is that society has its own laws and nature is only the frame of its activities (nihilism). Ferenc РвовÁLD (2012) pointed out that several variants of determinism can be distinguished according to the supposed range of environmentally controlled historical processes or social phenomena, the degree and (in)directness of environmental impact.

In Hungary, environmental determinism is a common phrase, but nihilism or possibilism is less known either in general or in scientific literature. These three phrases express theoretical ideas in the scientific approach of human-environment research (CASTREE, N. 2011; Harden, C.P. 2012; Judkins, G. et al. 2008; Lewthwaite, G.E. 1966; Peet, R. 1985; РRовÁld, F. 1999).

Postmodern geographical approaches use the contemporary philosophical thought, namely that the nature is a social construction. It also implies that its meaning is under permanent change depending on philosophical approaches and political aspects too (Demeritt, D. 2002). We agree that humanenvironment relations were differently evaluated from time to time; therefore, we present here these changes through time and space.

\section{The aspects of the newly professionalising geography}

In the second half of the $19^{\text {th }}$ and early $20^{\text {th }}$ centuries the evolution theory of Darwinism, the deductive research methods and the Newtonian causality largely affected the scientific thought (Grossman, L. 1977). For geography, which was on its way to become an academic discipline, it was a problematic question how to treat the place and role of humans within the great natural system of the Humboldtian synthesis. The research on the relations between humans and environment has resulted in the genesis of anthropogeography.

From a historical perspective, Hajdú (2007) claims, that the research on human-environment relations was a basic topic in the forming geographical science. According to István BERÉNYI (1997) this issue is connected to the classic (early) anthropogeography, which an- 
alysed the connections between humans and their natural and social surroundings. Tibor Mendöl (1999), who wrote the history of geography in the middle of the $20^{\text {th }}$ century, gave a different interpretation. According to him, in the end of the $19^{\text {th }}$ century geography was the science of connections and causalities in general. Our research group accepts the opinion of ProвÁLd (1999), who emphasised that the integrated analysis of spatial phenomena and the investigation of humanenvironment relations are among the most important targets of geographical research.

Discussing the role of scientific approaches and paradigms in geography, scientists who helped the process of paradigm formation should also be mentioned. The research on human-environment relations has appeared in geography from time to time, but the connecting paradigms had different stories through time and space. At the end of the $19^{\text {th }}$ century the German, French, British and American schools were equally engaged in human-environment research and anthropogeography. Four scientists got important positions at different universities at the same time, and they were interested in the research of society within the framework of the new science investigating the features of the Earth (CAstree, N. 2011). The German Friedrich RATZEL, the French Paul VidAL DE LA Blache, the British Halford Mackinder and the American William Morris Davis determined the scientific thought of humanenvironment relationships within the new academic discipline of geography.

All of them accepted the concept of unified geography that the research of nature and society is feasible within one discipline. With Mackinder's words, they believed, that geography can bridge the gap between physical and social sciences (CAstree, N. 2011). According to Davis the research on the relation between the Earth and its inhabitants is the task of geography, this research issue separate geography from other sciences (Lewthwaite, G.R. 1966; Harden, C.P. 2012). Their thought was influenced by the evolutionary theory of Lamarck and Darwin
(Livingstone, D.N. 2011). We can say that it was a compulsion to them to demonstrate the relationship between nature and society.

\section{Ratzel, determinism and their influence on scientific thought}

The result of the activity of Friedrich RATZEL from the German School was the determinist paradigm about human-environment relations, which dominated geographical thought for some decades. Due to his work this paradigm got scientific legitimacy, but later on it had a controversial career in history, not only in a scientific meaning. It has been transformed through time and space, but basically it remained the same. According to environmental determinism the environment, the nature controls human activities (Livingstone, D.N. 2011). As Hajdú (2007) commented environment determines the diverse development processes of society. Nature is the independent variable, the cause, while the human evolution and its social features are dependent variables, the answers to the cause (HARDEN, C.P. 2012).

Environmental determinism was not the product of academic geography, discoveries had already made it popular. This idea was propagated by several earlier writings, and especially the influence of climate on people was a popular theory (Livingstone, D.N. 2002). In the $18^{\text {th }}$ century, philosophers of the Enlightenment already wrote about the connections between the climate and the cultures. Geographic discoveries found various cultures at different latitudes, which were dissimilar from the European culture; therefore, the relation between climate and culture seemed quite obvious (Coombes, P. and BArber, K. 2005). Merely a modern science was necessary to legitimate this viewpoint. Geography became an academic discipline more or less the same time when western powers demanded the legitimacy of their colonial aspirations (Livingstone, D.N. 1992).

At the end of the $19^{\text {th }}$ and early $20^{\text {th }}$ centuries this thought was undoubtedly connected 
to geography and the reason for this was the subject of geographical research. According to LivingsTONE determinism served as a perfect basis for academic geography to provide an appropriate framework for the research of society. Second, it gave the scientific justification of colonial policies and so the spirit of the age made it successful (Livingstone, D.N. 2011).

Peet, R. (1985) confirms this view in his article about the social background of environmental determinism; according to him this idea was the entrance of geography to modern sciences. Darwinian thoughts in geography gave a scientific explanation to the question, why it is possible that certain nations are more successful than others in the struggle for world domination (PeEt, R. 1985). Consequently, environmental determinism is basically Eurocentric. Even nowadays we can meet scientific works based on the premise, that the formation of European culture was connected to special environmental features, or certain environmental features made non-European nations less resistant mentally and/or physically (Blaut, J.M. 1999; Castree, N. 2011).

RATZEL's works are deeply inspired by the evolutionary theory; he studied zoology, biology and anatomy in the 1860s (РeEt, R. 1985). He was a professor in Munich and later in Leipzig in the 1880s, when power efforts of the united German Empire became stronger; his thoughts gave the legitimacy of these imperialistic desires. According to BeréNYI (1992), in the works of RAtzel the physical environment determines the possibility of human activities, the spatial movement of people and their spatial distribution; therefore the development of a state is the function of the physical settings. MendöL (1999) emphasised that RATZEL had not claimed that every social phenomenon can be explained by environmental reasons; he just wanted to point those social phenomena, which really reflect the impact of environmental factors.

In Ratzelian thought the state is an organism under the rule of biological evolution, like every creature on Earth. Nations live on a given territory, which feed them; therefore, the need for a larger territory or living space
(Lebensraum) is instinctively present in their thoughts (Anderson, J. 2009). Later on, the living space theory had become notorious and compromised due to the book of Adolf Hitler (Mein Kampf), the Nazi ideology and the events of the Second World War. It is one of the reasons why environmental determinism disappeared from scientific thought and geopolitics in the second half of the $20^{\text {th }}$ century.

However, the influence of Ratzelian thoughts is far beyond German geography and geopolitics. In his study about the short history of the $20^{\text {th }}$ century geography ProвÁLD (1999) discussed the predominance of environmental determinism in American geography in the first part of the $20^{\text {th }}$ century too, thanks to the works of Ellen Churchill SEMPLE and Ellsworth Huntington. Semple was Ratzel's student in the 1890s in Berlin. Her often cited study was published in 1911 (Influences of Geographic Environment) and became very influential for decades in the United States (Peet, R. 1985; HARden, C.P. 2012). Sometimes, the work of Semple is mentioned as a separate geographical approach as environmentalism (LewTHWAITE, G.R. 1966, Рrobáld, F. 1999).

In her convincing theory SEmple emphasised the vitalising connection between Earth and man. Man cannot be investigated scientifically without the Earth, therefore, the aim of geography is to investigate the influence of natural factors on historical events (PEET, R. 1985). She investigated the effects of environment on human mind; this had involved the demonstration of mental features of nations and races. The basic thought, that the cradle of mankind is the hot zone, but the temperate zone offers the challenges and trigger higher-order development, had already appeared in RATzeL's works. However, SEMPLE went further: she described with spectacular examples the direct relation between nature and cultures (Peet, R. 1985). As Pál Teleki (1917/1996), wrote in his seminal work, Huntington went as far as to claim that the rise of civilisations is possible only in a certain climatic type of the Earth.

In the works of Semple, Huntington and their followers the environmental factors 
were "determinative causes of racial differences, cultural practices, moral values, ingenuity and the ultimate capabilities of any given population" (JudKins, G. et al. 2008. p. 20). Looking back, they are criticisable, because they drew consequences without well-documented causes and effects and without systematic research. They generated many stereotypes and legitimated racism too (HARDEN, C.P. 2012). According to Peet, R. (1985) determinism was popular in the United States in the early $20^{\text {th }}$ century, because this theory legitimated the declaration of the superiority of the American nation as well as their spatial expansion over the American continent.

Ratzelian thoughts were echoed in Hungarian geography much later. Research on human-environment relationships appeared only in the early $20^{\text {th }}$ century due to the works of Jenö CHOLNoкy, a prominent physical geographer and Géza Czirbusz known as the Hungarian apostle of anthropogeography. While Сноцnоку considered humans as one of the natural factors, Czirbusz advanced humankind from nature and he emphasised that other, more important internal effects have a significant role in the life of society (Fodor, F. 2006). Czirbusz considered RatzeL's thoughts and determinism with criticism and he called this theory "geographical fatalism". Therefore, Hajdú (2007) regards CHоLnоку a deterministic scientist, whereas he considers Czirbusz a possibilistic or even a nihilistic thinker.

The Ratzelian concept of natural barriers was an important argument in the Hungarian struggle for the revision of the borders set by the Treaty of Trianon (1920). ProbÁld (2012) emphasised the presence of determinism in Hungarian geography between the two world wars. He presented several examples to demonstrate that the works of geographers were differently affected by this idea. Only Ferenc Fodor formulated extremely deterministic thoughts in his late work, when he stated that all functions of the state are deeply rooted in the geographical features of its land. According to him, the character of the nations bears strong imprint even of environments their ancestors lived in many centuries ago.
Nevertheless, other Hungarian geographers, who investigated human-environment relations like Pál Teleki, Tibor MendöL, Gyula Prinz and András RónAI were closer to possibilism and the French School.

Environmental determinism provided a scientific basis for the early $20^{\text {th }}$ century scientists, who studied human phenomena in a changing world (Frenkel, S. 1992, 1994). According to HARDEN "the concept of environmental determinism, like the theory of continental drift, provided a stepping stone for the advancement of knowledge" (HARDEN, C.P. 2012, p. 740). Nevertheless, determinism got more and more critics within the scientific community from the 1920s that has led to a paradigm shift in geography after the Second World War. However, this over-simplifying theory had great popularity and it influenced political decisions until the fall of colonizer politics (FRENKEL, S. 1992, 1994).

\section{The critic of determinism: the impact of Paul Vidal de la Blache and the French School}

The influence of evolutionary theory is noticeable in the works of VIDAL DE LA BLACHE too (he used the expression 'struggle for existence'), but as a historian he was rather a social scientist. VIDAL DE LA BLACHE accepted the thought of unified geography; nature and society exist in one integrated system in his works, but he examined their relations from the side of the society. Teleki (1917/1996) quoted his thoughts about geography: according to him geography received many ideas from other disciplines, but equally offers them a lot, because geography has the possibility to consider things together, that were intimately joined by nature and to understand and to make understand the relations of phenomena, which are present in the whole nature including all of us, humans, and the different landscapes.

According to Vidal de la Blache humans have a relative autonomy from nature, people rate and use natural resources in different ways (BERÉNYI, I. 1997). His students em- 
phasised the importance of free will: "man is free to pick and choose between the vast but varying range of possibilities presented by his environment" (Lewthwaite, G.R. 1966, p 3; TeleKI, P. 1917/1996). As ProbÁLd (1999) wrote, the natural features could not determine the events of history, but provide a more or less wide range of possibilities. The utilisation of these possibilities depends on the cultural or technical development of the society.

In possibilistic thought the nature is an effective but not deterministic factor in the formation of differences between cultures. Environment gives possibilities to social activities. The humans as actors create their own culture and their environment through this (Anderson, J. 2009). The French Jean BRUnHES, a student of VIDAL DE LA BLACHE, emphasised that researchers must concentrate on interrelationships and not on unidirectional relations (Lewthwaite, G.R. 1966). According to BRUnHes, as humans become members of their community and accept their culture through socialisation, they exert an impact on nature too. They become factors affecting the environment, but there are many other factors influencing the nature, therefore, influencing humans too (TELEKI, P. 1917/1996). This is the essence of the human-environment relationship. His way of thinking was free from overstatements as it is reflected by his claim that every truth related to human-environment relations can be only approximate, and the overemphasis on precision leads to falsification (BRUNHEs, J. 1913).

VIDAL DE LA Blache examined smaller spatial units as opposed to the expanding state territories of his age; many landscape monographs were created by him and his followers (TELEKI, P. 1917/1996). He coined the term genres de vie (way of life) and he pointed out that spatial behaviour of human groups is primarily affected by cultural features. He did not draw general conclusions, instead he wanted to explore concrete relationships first. That is why he turned back to earlier data collection and classification methodology. He wanted to gather the characteristics of groups with certain ways of life. His re- search was rather descriptive focussing on the quantitative and qualitative categorisation of all features in a landscape (BERÉNYI, I. 1992; Mendöl, T. 1999; Anderson, J. 2009).

According to BERÉNYI (1997), the possibilism theory was the successor of determinism in time; the Ratzelian thought became an obsolete conception by the turn of the $20^{\text {th }}$ century due to the clear and intense transformation of nature by the upturning manufacturing industry. In fact, VIDAL DE LA BLACHE and RATZEL were active in almost the same time; therefore, it is more appropriate to say that these two viewpoints lived next to each other.

The influence of the French School and VIDAL DE LA BLACHE penetrated to other countries, too. The concept of synthetic geography of TELEKI, the prominent Hungarian geographer of the interwar period was closely connected to this approach. He was enthusiastic about the ingenuity of landscape monographs, but he considered them methodologically primitive (TELEKI, P. 1917/1996). According to him, the mission of geographical description is to introduce the characters of landscapes and the comparison of them, searching for typical differences and similarities (Teleki, P. 1917/1996).

Possibilism could be used as a kind of scientific support to Hungarian irredentist efforts. Zoltán KrasznaI (2003) pointed out that using ideas of the French School in the Paris Peace Conference was a tactical step. According to their concept, the Carpathian Basin is a complex of landscapes, which complete each other (GYôRI, R. 2009). The monograph of the Carpathian Basin is the last product of this idea (Bulla, B. and MendöL, T. 1947). The influence of the French School can be recognised in the theoretical studies of István DÉKÁNY and in the works of Tibor MENDÖL, too (HAjdú, Z. 2007; GYốr, R. 2009).

The predominance of descriptive geography became more and more obvious internationally till the remarkable paradigm shift after the Second World War. In the 1920s, the scientific arguments against determinism in the American geography used the approach of possibilism. These arguments and 
the basis of the human ecological approach are connected to Carl Sauer (Williams, M. 1994; JudKins, G. et al. 2008). In addition to the importance of the free will, SAUER emphasised that nature offers or limits certain possibilities, but does not determine the culture (HARDEN, C.P. 2012). He stated that the human behaviour is not dependent on environmental constrains or on logical necessity but rather on the conventions acquired in the culture. His research methodology took into consideration the historical development and used inductive methods like VIDAL DE LA BLACHE, he presented how the culture and the physical environment can be studied in an integrated framework and context. (JUDKINS, G. et al. 2008). Another similarity, that SAUER performed his research using small territorial units too. He called them cultural landscapes, emphasising that they are the results of the joint influence of culture and nature (Harden, C.P. 2012).

In the American geography, the ecological views appeared in the 1920s starting mainly with the research of SAUER who worked with some anthropologists at Berkeley University. His follower, Harlan BARrows emphasised that human ecological research can provide the appropriate framework for the unified geography by the exploration of relationships between humans and the environment (Grossman, L. 1977; Harden, C.P. 2012). The early ecological studies of SAUER and his school concentrated principally to the prints of the society recognisable in the cultural landscape (Grossman, L. 1977).

\section{Study of human-environment relations in the bipolar world}

The new political system formed after the Second World War established different research conditions, ideas and directions in the opposing countries of the capitalist and the communist blocks. We have to study the theoretical and ideological aspects of both sides in order to outline the further evolution of human-environment research in geography.
Communism and human-environment relationships.

According to Hajdú (1999) both determinism and nihilism were present in pre-revolution Russian geography, but just after the Soviet takeover possibilism became the dominant approach. Later on, possibilism changed place with nihilism and social determinism due to the building up of the Stalinist system and the ambitious state plans for nature transformations, though communist geographers would have protested against this categorisation. RADó, S. (1962) emphasised that Soviet geographers equally rejected the bourgeois environmental determinism, the geographical possibilism and the American environmentalism.

The scientific life of the Soviet Block was under the rule of one exclusive ideology: the dialectical and historical materialism of Marx and Engels. This ideology postulates the mutual relations of phenomena; therefore, it offered an intellectual direction to Eastern Block geographers how to think about human-environment relations (VAviLov, Sz.I. 1950).

According to MARX, a connecting process, the work determines the relationship between humans and nature. This process is associated with humans, who transform the environment and through this themselves. Nature provides different conditions to people. Societies depending on their degree of development use different natural resources during the production. Because of this relationship those territories of the Earth where natural resources are rich do not force people to develop themselves. Several Hungarian scientific works used the thoughts of MARx to explain why the motherland of the capital was not the tropical climate with its overgrowing vegetation, but the temperate zone. Certainly, Marx was influenced by the scientific results of his age (evolutionary theory, information from discoveries), therefore, the dialectical and historical materialism helped to develop deterministic thoughts in geography. However, he unambiguously declared that the work and the production hereby the humans are the motive force of events. 
Humans were emancipated from the environment through work and production and the society depending on its degree of development dominates nature (Sмітн, N. 1990).

Not only the investigation of human-environment relationships, but even the hard separation of humans and nature became the ideological basis of the Marxist-Leninist geography. Nevertheless, during everyday research practices these ideas were in the service of actual political reasons and they were interpreted as it was advantageous for decision makers. According to ENGEL-Di Mauro (2009), the strict catechism followed by geographers was similar to the parody of Marx's works (Engel-Di Mauro, S. 2009). The geographical investigations were under state control, in service of the planned economy. Physical and human geography were separated from each other, and the later was replaced by economic geography, which pointed out the research directions (TIMÁR, J. 2009).

Science must be useful for society and it must serve the resolution of tasks set by the state, therefore, only applied research was favoured in the Eastern Block (VAvilov, Sz.I. 1950). On the other hand, science in the communist era was based on positivism, searched for objective truth and believed that the world is knowable (VAvilov, Sz.I. 1950). Eastern Block geographers were rather thinking in a system of geographical sciences because of specialisation processes dissecting geography (RADó, S. 1962). Research was structured into two almost completely distinct units: physical and economic geography. Physical geography investigated the scene of production, the natural environment; therefore, it prepared the study of economic geography.

In the Stalinist era, the task of the Soviet science was the service of monumental plans, like industrialisation, military preparations or the notorious environment-transformations (Shaw, D.J.B. and Oldfield, J.D. 2007). Practically, it led to the most simplistic interpretation of human-environment relations: society stands above nature and society is able to form and to transform nature in any way according to its needs (SHAw, D.J.B. and
OldFIELD, J.D. 2007). As geography served the coloniser ambitions of the Western countries earlier, so was it used by the Soviet politics to support the actual nature-transforming state plans. It was a total compulsion for them, they did not have a choice; they had to serve the dictatorship. According to Hajdú (1999), the science of geography acted in fact in the propaganda of the works, and not in the formulation of plans. In the 1970s the negative environmental effects of the grand plans became so obvious that it inspired scientists to reconsider human-environment relationships again. Regional landscape research reappeared and new investigations with more qualitative methods as well as research themes from other fields of human geography (not economy) could begin (SHAw, D.J.B. and OldField, J.D. 2007; Timár, J. 2009).

These developments were also valid for Hungary, where the sovietisation of science and of geography took place at the end of the 1940s. The end of this era when most studies neglected the environment can be assigned to the study of György ENYEDi (1972). He discussed how much environmental factors were ignored in the study of social development. His work indicated the rethinking of nature-society relations in the early 1970s.

\section{The changing Western geography and the nature-society dichotomy}

The concept of paradigm shift can explain the ignoration of human-environment relationships in geography after the Second World War (KuHN, T.S. 1984). In the Western world the quantitative revolution and the spatial science approach, which endured till the 1980s pushed human-nature relationships aside during the second half of the $20^{\text {th }}$ century (PRobáld, F. 1999).

First, the abovementioned paradigm shift occurred mainly after the Second World War thanks to the specialisation of geographical research. Development of geomorphology, climatology, economic geography and political geography in the early $20^{\text {th }}$ century 
was the forerunner of this fragmentation. Specialisation of human geography isolated the environmental studies. Physical geography focussed on Earth surface phenomena, but not in a holistic manner, instead even research on the physical environment was distributed into several sub-disciplines (CAstree, N. 2011).

Second, the connection of determinism with coloniser efforts, racist views and Nazi ideas made it undesirable to both policy and society. Because of its intolerable situation, scientists discarded environmental determinism in the Anglo-Saxon world. As we mentioned earlier, environmental determinism was the entrance of geography to modern sciences, therefore, geography had to be rebuilt from its basis. The breaking with determinism pushed into background all kinds of research related to human-environment relationships. But there remained a vacuum after it in geographical science, and similar unifying paradigms have never appeared again since that time that would promote the investigation of human-environment relationships (GUELKE, L. 1989).

Besides this, Probáld (1999) explains the decline of determinism by a change of the way of thinking which appeared in the developed countries in the 1950s and 1960s. This new way of thinking is based upon the absolute faith in technical development that cannot accept any controlling act of nature. He did not call it nihilism, but he considered it as a backlash to the earlier deterministic thought. After the Second World War the role of science in society has changed radically and geography also had to adjust to it. The quantitative revolution in geographical science as well as the spatial science approach of the discipline further reduced the connections between physical and human geography (Guelke, L. 1989).

In the second half of the $20^{\text {th }}$ century the human-environment research was basically ignored in geography but continued in other disciplines. Historians of the French Annales School analysed the relationships of different societies and the space around them
(Braudel, F. 1949; Chaunu, P. 1966). After the specialisation of ecological research, there appeared some topics, which promoted the investigation of human-environment relationships, like cultural ecology, human ecology or political ecology. Cultural ecology became significant among anthropologists after the Second World War. Besides the relationships between cultures they investigated also the relations between different cultures and their environments (Grossman, L. 1977). The ecological idea enriched the works of archaeologists too (Renfrew, C. and BAHN, P. 1996).

Thanks to possibilism, human-nature research was present in geography too, but in a changed form and not in the focus of scientific attention. The ecological research as we mentioned above has already appeared in the early $20^{\text {th }}$ century in American geography. Cultural and political ecology appeared after the second half of the $20^{\text {th }}$ century; they interpreted the causality between humans and their environment from both directions (HARDEN, C.P. 2012). This idea presumed the correlations between special environmental characters and cultural traditions (JudKINs, G. et al. 2008).

Cultural ecology became significant particularly in American geography in the 1960s due to the works of Julian StewARd, Roy Rappaport and Clifford Geertz (Castree, N. 2011). They investigated the adapting processes of humans to nature (HARDEN, C.P. 2012). They focused on the changing processes caused by human activities (e.g. the effect of soil erosion, burning and cutting of vegetation), and analysed mainly the local features of smaller communities (Grossman, L. 1977).

Political ecology investigated how the political and economic structures explained the interaction between society and its environment (Harden, C.P. 2012). According to the approach of structuralism in political ecology, the society is the main determining factor through its institutions (JUDKINs, G. et al. 2008).

As the structuralism appeared in geography, the models of ecosystems worked out by biologists came also into use. These models were a great leap forward, because ecosystem analysis provides a useful framework to the 
investigation of mutual human-environment interactions (Grossman, L. 1977). However, instead of ecosystem analyses, the investigation of spatiality, and spatial analysis became dominant in geography. The building of models and macro-regional investigations became characteristic, therefore, the ecosystem analyses, which were used mainly in small scale research, were not adopted.

Nonetheless, the ecological research gave dynamics to the study of man-environment relationships again. Instead of looking for simple casual relationships, it revealed the complexity of links between humans, society and environment (HARDEN, C.P. 2012). These investigations focused mainly on smaller communities and territorial units of developing countries during the second half of the $20^{\text {th }}$ century (HARDEN, C.P. 2012).

\section{New approaches around the millennium}

The real breakthrough in human-environment research ensued in the 1990s, when the idea that humans have an influence on recent climate change was accepted (Coombes, P. and BARBER, K. 2005). The environmental protection movements appeared first in the United States in the 1960s and 1970s and gradually gained political support to study these questions and increased research activities in these fields (HARden, C.P. 2012). The global climate change discourse received geopolitical importance and turned the attention to the fragile relation of humans and their environment. The environmental problems emphasised by politicians and the need for solving these problems generated a social claim towards science to study these questions (Judkins, G. et al. 2008). In the $21^{\text {st }}$ century, investigation of human-environment relationships have become more significant not only in geography but in other social sciences too.

These emerging issues have constituted a real challenge for geography. In the past decades, due to Holocene research and new scientific methods, the investigation of hu- man impact on natural environment became an important topic (Builth, H. et al. 2008; LÉPY, E. 2012). The climate change discourse raises again the question that environmental changes can radically transform the life of societies. Many studies indicated correlation between climate change and cultural disasters (CoOmbes, P. and BARber, K. 2005). These studies emphasise the need for understanding these effects in order to reduce, stop or reverse the undesired results (Harden, C.P. 2012).

There is a peculiar chapter in human-environment research, the investigation of factors, which mean risks to human communities and society needs protection against them (CAstree, N. 2011). In this viewpoint, the natural factors are the independent variables again; they influence the life of communities (Harden, C.P. 2012). These viewpoints also gained more importance as recent climate change became a favourite subject.

While the once ruling paradigm of environmental determinism was expelled from geography, it appeared again and even flourished (!) in other disciplines (Hulme, M. 2011). Biologists, historians, anthropologists and economists also investigate the role of natural factors in social processes and ask even basic questions like why certain nations are richer than others (SCHOENBERGER, E. 2001). While some economists, historians and climatologists formulated extremely deterministic and sometimes absurd statements (e.g. LANDES, D.S. 1998, BeHringer, W. 2010), the mainstream geography consistently rejected every sign of environmentalism (e.g. BLAUT, J.M. 1999; JudKins, G. et al. 2008; O'Keefe, P. et al. 2009). However, we emphasize that geography must react to these environmentalist thoughts, in some cases even by adopting some less strict forms of environmental determinism (Diamond, J. 1997; RAdCliffe, S.A. 2010). If any connection can be observed between environmental change and subsequent cultural transformation, the geographical community is inclined to think about deterministic relations (NuNN, P.D. 2003). Since these investigations are connected mainly to 
Quaternary research, the neodeterministic approach appears principally in the works of physical geographers (NunN, P.D. 2003; O'KeEFe, P. et al. 2009).

\section{The challenges of the future}

After we get acquainted with several works about human-environment relations, we can support the significance of this topic in our discipline. It is one of the most basic questions in geography; it gave the basis of becoming an academic discipline, and it greatly influenced its dual character in the $19^{\text {th }}$ century. The nature-society dichotomy resulted different approaches in different periods and places, and it accompanied the whole history of geography.

Recently, research on human-environment relationships reappeared due to the discourse of global climate change. Many scientists have denoted the risks and unscientific nature of classical deterministic thought (e.g. Sluyter, A. 2003). However, the ecological approaches, used in anthropology and archaeology, give an alternative, which emphasises the active role of people reacting to climate changes being in a dynamic relation with their own environment - they form and transform it (ERICsON, C.L. 1999). At the turn of the millennium the scientific community takes steps for the integration of ecological approaches with an actor oriented viewpoint. They would like to understand how the individuals can manipulate their own situations in the ecological, structural and cultural framework, in which they live (Judkins, G. et al. 2008). Despite the popularity of deterministic approach between laics and politicians, the scientific community investigates the human-environment relationships rather from an ecological point of view (Builth, H. et al. 2008; LÉPy, É. 2012; RAYMOND, C.M. et al. 2013).

Postmodern, poststructuralist, and postcolonial approaches have radically changed the philosophy of human-environment research in social sciences. According to these viewpoints, every representation of the nature is a social construction, the manifestation of some kind of social power. Thus, these approaches turn the idea of environmental determinism inside out, and they also point to the fact that the mental separation of nature and society, which is the basic of most human-environment concepts, is a heritage of Western philosophy (CAstree, N. 2011).

Not only the global problems or the changing ideology of postmodern world induce the science to investigate human-environment relations. Due to the information revolution more effective equipment and better analysis methods are available for the scientific community; therefore, it is worth rethinking the relationships between humans and their environment.

The geographical science has to renew not only its philosophical basis and scientific terms, but the connections between the two subdisciplines of geography (i.e. between physical and human geography) must be refreshed too. The scientific community frequently emphasises the importance of multidisciplinary research and in the case of geography, this multidisciplinary approach can be achieved by coordinating the physical and human geographical investigations. The success of this coordinated research can be a key factor in the survival or renaissance of our discipline. Human-environment studies may have an important contribution to these efforts. Perhaps it is time for geography to reconsider its suspiciousness and hypersensitivity against all variants of determinism.

Acknowledgement: This research has been supported by the Hungarian National Science Foundation, OTKA 104811 project. The work of Tamás TelBisz has been supported by the János Bolyai Scolarship of the Hungarian Academy of Sciences. 


\section{REFERENCES}

Anderson, J. 2009. Understanding of Cultural Geography: Places and Traces. Routledge, London, $240 \mathrm{p}$.

Behringer, W. 2009. A Cultural History of Climate. Cambridge, Polity Press, $280 \mathrm{p}$.

BERÉNYI, I. 1992. Az alkalmazott szociálgeográfia elméleti és módszertani kérdései (The Theoretical and Methodological Questions of Applied SocioGeography). Budapest, Akadémiai Kiadó, 168 p.

BERÉNYI, I. 1997. A szociálgeográfia értelmezése (Definition of Socio-Geography). Budapest, ELTE Eötvös Kiadó, 136 p.

BLAUT, J.M. 1999. Environmentalism and Eurocentrism. The Geographical Review 89. (3): 391-408.

Braudel, F. 1949. La Méditerranée à l'époque de Philippe II. In Hungarian: A Földközi-tenger és a mediterrán világ II. Fülöp korában. Budapest, 1996, Akadémiai Kiadó, $1465 \mathrm{p}$.

BRUNHES, J. 1913. Emberföldrajzi problémák (Anthropogeographical problems). Földrajzi Közlemények 41. 320-342.

Builth, H., Kershaw, A.P., White, C., Roach, A., Hartney, L., McKenzie, M., Lewis, T. and Jacobsen, G. 2008. Environmental and cultural change on the Mt Eccles lava-flow landscapes of southwest Victoria, Australia. The Holocene 18. (3): 413-424.

Bulla, B. and MendöL, T. 1947. A Kárpát-medence földrajza (Geography of the Carpathian Basin). Budapest, Egyetemi Nyomda, 611 p.

Castree, N. 2011. Nature and Society. In The SAGE Handbook of Geographical Knowledge. Eds.: AGNEw, J.A. and Livingstone, D.N., London, SAGE Publications, 287-299.

Chaunu, P. 1966. La civilisation de l'Europe classique. In Hungarian: A klasszikus Európa. Budapest, 2001, Osiris, $536 \mathrm{p}$.

Coombes, P. and Barber, K. 2005. Environmental determinism in Holocene research: casuality or coincidence? Area 37. (3): 303-311.

Demeritt, D. 2002. What is the "social construction of nature"? A typology and sympathetic critique. Progress in Human Geography 26. (6): 767-790.

Diamond, J. 1997. Guns, Germs and Steel: The Fates of Human Societies. New York, W.W. Norton \& Company, $460 \mathrm{p}$.

EngeL-Di MAuro, S. 2009. Socialism. In International Encyclopaedia of Human Geography 1. Eds.: Kiтchin, R. and Thrift, N. Oxford, Elsevier, 214-220.

ENYEDI, Gy. 1972. A társadalom és földrajzi környezete (The Society and its Geographical Environment). Földrajzi Közlemények 20. (4): 293-301.

ERICKson, C.L. 1999. Neo-environmental determinism and agrarian 'collapse' in Andean prehistory. Antiquity 73. (281): 634-642.

FoDor, F. 2006. A magyar földrajztudomány története (History of geography in Hungary). Budapest, MTA Földrajztudományi Kutatóintézet, 820 p.
FRENKEL, S. 1992. Geography, Empire and Environmental Determinism. Geographical Review 82. (2): 143-153.

Frenkel, S. 1994. Old theories in New Places? Environmental Determinism and Bioregionalism. Professional Geographer 46. (3): 289-295.

Grossmann, L. 1977. Man-environment Relationships in Anthropology and Geography. Annals of the Association of American Geographers 67. (1): 126-144.

GueLKE, L. 1989. Intellectual Coherence and Foundations of Geography. Professional Geographer 41. (2): 123-130.

GYốRI, R. 2009. Tibor Mendöl(1905-1966). In Geographers. Biobibliographical Studies. 28. Eds.: Lorimer, H. and Withers, C.W.J., London, Continuum, 39-54.

HAJDú, Z. 1999. Környezet és politika: a természetátalakítás „zseniális" sztálini terve (Environment and politics: the "genius" Stalinist plan for nature transformation). In Változó környezetünk: tiszteletkötet Fodor István professzor úr 60. születésnapjára. Eds.: Tóth, J. and WiLhelm, Z., Pécs, JPTE, 131-145.

HAJDú, Z. 2007. A földrajzi nihilizmus, a földrajzi determinizmus és a földrajzi posszibilizmus (The geographical nihilism, determinism and possibilism). In A területfejlesztés földrajzi alapjai. Ed.: PAP, N., Pécs, PTE TTK Földrajzi Intézet, 39-55.

Harden, C.P. 2012. Framing and Reframing Questions of Human-Environment Interactions. Annals of the Association of American Geographers 102. (4): 737-747.

Hulme, M. 2011. Reducing the Future to Climate: a Story of Climate Determinism and Reductionism. Osiris 26. (1): 245-266.

Judkins, G., Sмith, M. and KeYs, E. 2008. Determinism within human-environment research and the rediscovery of environmental causation. The Geographical Journal 174. (1): 17-29.

KrasznaI, Z. 2003. Szakértelem és geopolitika. Földrajztudósok az első világháború után: Emmanuel de Martonne és Teleki Pál (Competence and Geopolitics. Geographers after the First World War: Emmanuel de Martonne and Pál Teleki). In Léptékváltó társadalomtörténet. Benda Gyula tiszteletére. Eds.: Horváth, Zs., Lugosi, A. and Sohajda, F. Budapest, Hermész Kör-Osiris, 345-365.

Kunn, T.S. 1962. The Structure of Scientific Revolutions. In Hungarian: A tudományos forradalmak szerkezete. Budapest, 1984, Gondolat, 324 p.

Landes, D.S. 1998. The Wealth and Poverty of Nations. Why Some are so Rich and Some so Poor. New York, W.W. Norton \& Company, 650 p.

LÉPY, É. 2012. Baltic Sea and environmental and societal implications from the comparative analysis of the Bay of Bothnia and the Gulf of Riga. Fennia 190. (2): 90-101.

Lewthwaite, G.R. 1966. Environmentalism and determinism: a search for clarification. Annals of the Association of American Geographers 56. (1): 1-23.

Livingstone, D.N. 2011. Environmental determinism. In The SAGE Handbook of Geographical Knowledge. 
Eds.: Agnew, J.A. and Livingstone, D.N., London, SAGE Publications, 368-380.

Livingstone, D.N. 1992. The Geographical Tradition. Oxford, Blackwell, 434 p.

Livingstone, D.N. 2002. Race, space and moral climatology: notes toward a genealogy. Journal of Historical Geography 28. (2): 159-180.

MendöL, T. 1999. A földrajztudomány az ókortól napjainkig (Geography from the Ancient Times to Present days). Budapest, ELTE Eötvös Kiadó, 276 p.

NunN, P.D. 2003. Revising ideas about environmental determinism: Human-environment relations in the Pacific Islands. Asia Pacific Viewpoint 44. (1): 63-72.

O'Keefe, P., O’Brien, G., Gadema, Z. and Swords, J. 2009. Geographers and Geography: making waves for the wrong reasons. Area 42. (3): 258-261.

Peet, R. 1985. The Social Origins of Environmental Determinism. Annals of the Association of American Geographers 75. (3): 309-333.

Probáld, F. 1999. A földrajz fejlődése a XX. század második felében (Development of geography in the second half of the $20^{\text {th }}$ century). In A földrajztudomány az ókortól napjainkig. Ed.: MendöL, T., Budapest, ELTE Eötvös Kiadó, 224-257.

PRobÁLD, F. 2012. Egy elfeledett geográfus lappangó múve: "A magyar lét földrajza" (Hidden manuscript of a forgotten geographer: "Geography of the Hungarian state of being"). Földrajzi Közlemények 136. (4): 453-458.

Radcliffe, S.A., Watson, E.E., Simmons, I., FernandezArmesto, F. and Sluyter, A. 2010. Environmentalist thinking and/in geography. Progress in Human Geography 34. (1): 98-116.

RADó, S. 1962. A kommunizmus építése és a földrajzi tudományok (Building of Communism and the Geographical Sciences). Földrajzi Közlemények 86. (3): 225-232.

Raymond, C.M., Singh, G.G., Benessaiah, K., Bernhardt, J.R., Levine, J., Nelson, H., Turner, N.J., Norton, B., TAM, J. and Chan, K.M.A. 2013. Ecosystem Services and Beyond: Using Multiple Metaphors to Understand Human-Environment Relationships. BioScience 63. (7): 536-546.

Renfrew, C. and Bahn, P. 1996. Archaeology. Theories, Methods and Practice. In Hungarian: Régészet. Elmélet, módszer, gyakorlat. Budapest, 1999, Osiris, 644 p.
Schoenberger, E. 2001. Interdisciplinarity and social power. Progress in Human Geography 25. (3): 365-382.

Shaw, D.J.B. and Oldfield, J.D. 2007. Landscape Science: A Russian Geographical Tradition. Annals of the Association of American Geographers 97. (1): 111-126.

Sluyter, A. 2003. Neo-Environmental Determinism, Intellectual Damage Control, and Nature/Society Science. Antipode 35. (4): 813-817.

Sмiтн, N. 1990. Uneven Development: Nature, Capital and the Production of Space. Oxford, Blackwell, 34-65.

Telbisz, T., Bottlik, Zs., Mari, L. and Köszegi, M. 2014a. The Impact of Topography on Social Factors, a Case Study of Montenegro. Journal of Mountain Science 11. (1): 131-141.

Telbisz, T., Bottlik, Zs., Mari, L., Petrvalská, A., Kőszegi, M. and Szalkai, G. 2014b. Természeti tényezők hatása a népesség területi eloszlására a Gömör-Tornai-karszt és tágabb környezete példáján (The impact of physical environment on the spatial distribution of population. A case study of Gömör-Torna Karst and its surroundings). Földrajzi Közlemények 138. (4): 277-292.

Telbisz, T., Imecs, Z., MARI, L. and Bottlik, Zs. 2014c. Földrajzi posszibilizmus vizsgálata az Erdélyiszigethegység példáján (The study of geographical possibilism theory using the Apuseni Mountains as a case example). Karsztfejlódés 19. 23-40.

Teleki, P. 1917. A földrajzi gondolat története (The history of geographical thought). New edition: Budapest, 1996, Kossuth, 196 p.

Timár, J. 2009. Communist and Post-Communist Geographies. In International Encyclopaedia of Human Geography 1. Eds.: Kitchin, R. and Thrift, N., Oxford, Elsevier, 214-220.

VAvilov, Sz.I. 1950. A sztálini korszak tudománya (The science of the Stalinist era). Budapest, Szikra, 128 p.

Williams, M. 1994. The relations of environmental history and historical geography. Journal of Historical Geography 20. (1): 3-21. 


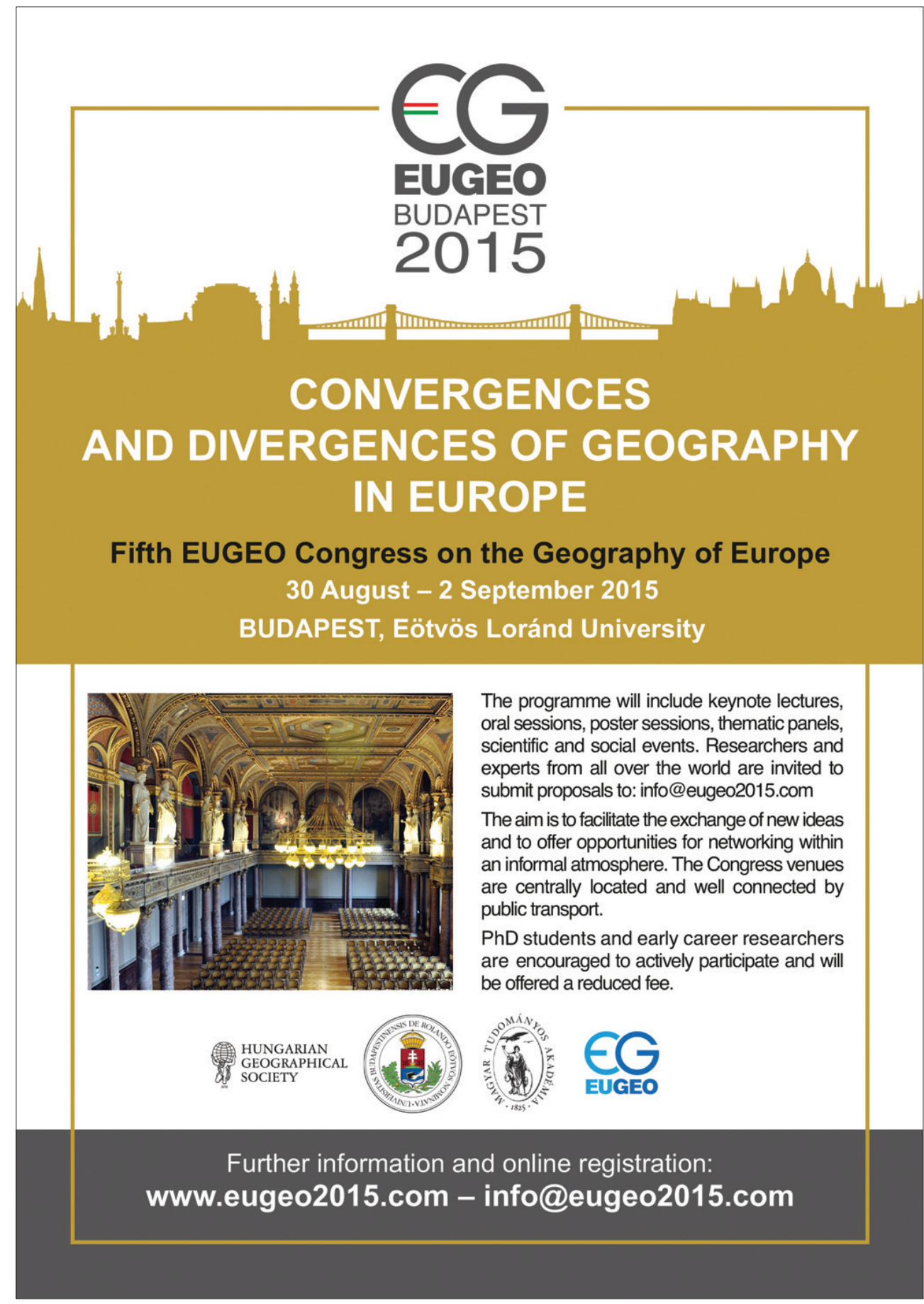

